\title{
平面壁上の有限長円柱を過きる流れ*1 \\ Flow past Circular Cylinder of Finite Length Placed on Ground Plane
}

\author{
岡 本 史 紀*2 \\ Shiki OKaмото
}

\begin{abstract}
Key Words: Turbulent Flows, Circular Cylinder, Surface Pressure, Drag, Vortices,
\end{abstract} Velocity Defect, Turbulence, Wake

\begin{abstract}
This paper describes an experimental study of the changes of vortices formation and turbulent wake from a circular cylinder with the slenderness of cylinder, placed on a ground plane. The experiment was carried out in an N.P.L. blow down type wind-tunnel having a working section of $500 \mathrm{~mm} \times$ $500 \mathrm{~mm} \times 2,000 \mathrm{~mm}$ in size at the Reynolds number $2.5 \times 10^{4}$ to $4.7 \times 10^{4}$. The surface-pressure distributions on the circular cylinder were measured and the drag coefficient was determined from them. The vortices of two kinds generated in the flow-field around a circular cylinder have also been observed and the velocity defects and turbulent intensities in the turbulent wake behind a circular cylinder were measured. Consequently, it is found that the flow pattern changes rapidly from $H / D=4$, while the shedding vortices change from arch type to Karman type.
\end{abstract}

\section{1. 楮言}

近年，煙突、ガスタンク，冷却塔など円形断面をも つ構造物まわりの流れが棈造設計または大気污染問題 から重要視されているため，平面壁上の有限長円柱ま わりの研究が多くなされている。

促来の研究は，煙突などのように大縦横比の円柱に ついて行ったものが多く ${ }^{1,2)}$ ，円柱自由先端の影響を 中心に調べられてきだ、4.しかし最近では，ガスタ ンクなどのような絴横比が小さい円柱についての実験 も行われておりら，著者は $H / D=1$ の円柱でも周期的 な流出渦が存在し、それはカルマン渦とは異なったア 一チ渦という対称渦であることをすてに報告しだ． したがって円柱の縜横比が大きくなるにつれて円柱か らの流出渦はアーチ渦からカルマン渦へ㚆化するもの

\footnotetext{
*1 昭和 62 年 9 月 24 日原稿受理

*2 芝浦工業大学工学部機械工学科
}

と考えられ，それにともなって表面圧力および乱流後 流も異なる様相を呈するものと思われる。しかし，い ままで円柱の縦横比による円柱まわりの表面圧力, 抗 力, 乱流後流内の速度分布について調べたものはある が，流出渦の変化過程については，わずかに谷口らの 研究51以外には見当たらない. 本研究の目的は $H / D=$ 5 前後の円柱を用いて, 流出渦がアーチ渦からカルマ ン渦に移行する過程ならびにそれに伴う表面圧力およ び乱流後流における変化を詳細に調べことである．

$$
\text { 記 号 }
$$

$$
\begin{aligned}
& C_{\mathrm{D}}: \text { 抗力係数 } \\
& C_{\mathrm{p}}: \text { 圧力係数 }\left(=\left(p-p_{\infty}\right) /\left(\rho U_{\infty}{ }^{2} / 2\right)\right) \\
& D: \text { 円柱の直径 } \\
& F_{n}: \text { エネルキススペクル関数 } \\
& H: \text { 円柱の高さ } \\
& n: \text { 渦流出振動数 } \\
& p: \text { 静压 } \\
& p_{\infty}: \text { 主流 } U_{\infty} \text { に対する静压 } \\
& R e: \text { レイノルス数 }\left(=D U_{\infty} / \nu\right) \\
& S t: \text { ストラハル数 }\left(=D n / U_{\infty}\right) \\
& U: \text { 時間平均速度 } \\
& U_{\infty}: \text { 主流速度 }
\end{aligned}
$$

$u^{\prime}, v^{\prime}, w^{\prime}: X, Y, Z$ 方向における速度変動

$X, Y, Z:$ 円柱の底面中心に原点をもつ直角座標, 主流方向に $X$ 軸，それに直角な水平方向 にY 軸，鉛直方向に $Z$ 軸をとる（第 1 図)

\section{$X_{r}$ : 再循票領域の長さ}

$\theta:$ 円柱前方よどみ点からの円周上の点の角 度

$\nu:$ 空気の動粘性係数

$\rho:$ 空気の密度 


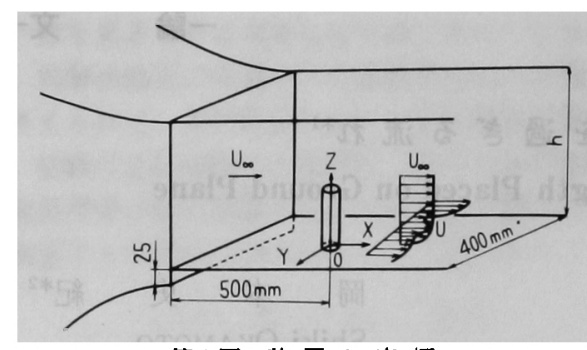

第1図震と座標

\section{2. 実験装畳および実験方法}

実験に使用した風洞は $500 \mathrm{~mm} \times 500 \mathrm{~mm}$ の正方形 断面をもつ N.P. L.ブローダウン式風洞で，測定部の 長さは $2,000 \mathrm{~mm}$ てある.風洞壁面において発達した 境界層を避けるため，地面板は風洞壁面から上方に $25 \mathrm{~mm}$ だけ離して取り付けた．円柱の取付け位置は 前縁から $500 \mathrm{~mm}$ 下流位置であるが，この位置におけ る境界層の厚さは約 $4 \mathrm{~mm}$ てあった (第 1 図). 円柱の 種類は高さ $(H)$ の直径 $(D)$ に対する比つまりアスペ クト比 $(H / D)$ を $H / D=0.5,1,2,4,7$ の 5 通りとした. なお，表面圧力の測定ては $H / D=0.5,1$ て は $D=70$ $\mathrm{mm}, H / D=2,4$ では $D=40 \mathrm{~mm}, H / D=7$ ては $D=$ $30 \mathrm{~mm}$ の円柱を用い，後流測定では $H / D$ のすべての パラメータにおいて $D=20 \mathrm{~mm}$ の円柱を用いた。 三 次元物体に対する風洞壁の閉塞影䅉については， Farell-Carrasquel-Güven-Patel の研究")により，流 れに対する物体の投影断面積が風洞測定部断面程の 5\%以下であれば無視できることが明らかにされてお り. 本実験では $D=70 \mathrm{~mm}$ の $H / D=1$ の円柱でも面

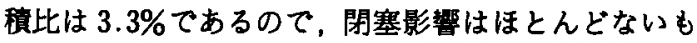
のと考えられる。

円柱の表面には $0.5 \mathrm{~mm} \phi$ の静圧孔があけてあり。 表面全体の圧力が湘定できるように円柱は $360^{\circ}$ 回転 可能て底面より压力を取り出すこととする，流れのは く踓と渦の形成については，回流水槽を用い可視化 し，観察を行った。また，円柱背後の乱流後流の平均 速度，乱れ強さ，エネルギスペクトル，流出渦の振動 数の測定ではピトー管, 定温度型熱線流速計, バンド パスフィルターを用いた，座標系は円柱底面中心を原 点とし，流れ方向に $X$ 軸，それに垂直な方向を $Y$ 軸，円柱軸方向を $Z$ 軸とする. 主流速度は $U_{\infty}=10.2$ $\sim 19 \mathrm{~m} / \mathrm{s}$ ，このときのレイノルス数は臨界レイノル ス数以下の $R e=U_{\infty} D / \nu=2.5 \times 10^{4} \sim 4.7 \times 10^{4}$ で実験 を行った.

\section{3. 実験結果とその考察}

3.1 表面圧力分布，抗力係数 $H / D=1$ の有限镹

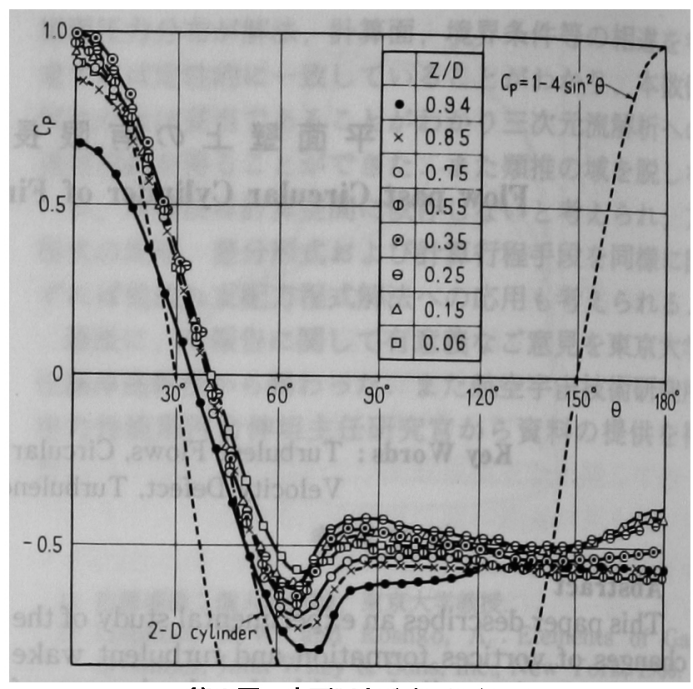

第 2 図 表面仕力分布 $(H / D=1)$

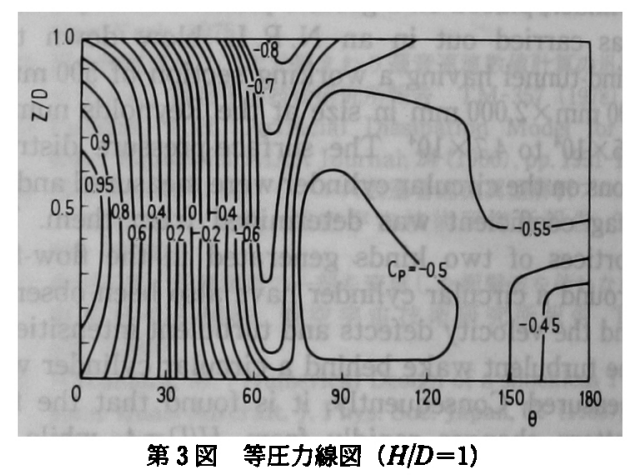

円柱側面の表面圧力分布を第 2 図に示す．図中の破線 はポテンシャル流れの理論による $C_{p}=1-4 \sin ^{2} \theta$ の 值を表したものてある.この図を見ると，自由先端付

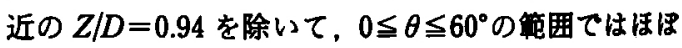

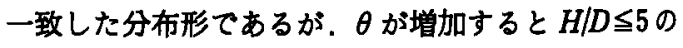
有限長円柱では円柱自由先端の影篦が根元まて及んて いることから ${ }^{3)}, 60^{\circ} \leqq \theta \leqq 180^{\circ}$ の筑囲における压力保 数の值は，Z/Dの值により差が生じる. 測定したこ れらの曲線より．円柱側面の等圧力線図を描いたもの が第 3 図、第 4 図である. 第 3 図の $H / D=1$ の場合の 等圧力線図を見ると，円柱自由先端の影管は背面にお ける圧力変化に影著に現れており，等圧力線が背面に おいても根元付近まてのびていることから，先端の影 整は円柱の付根にまて及んている．また円柱の自由先 端より $0.5 D, \theta=70^{\circ}$ 付近に压力が低くなる部分，す なわち圧力の谷が現れていることが明らかてある.他 方，第 4 図の $H / D=7$ の場合の等圧力線図を見ると，

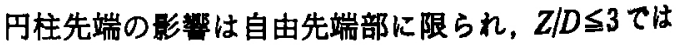
$Z$ 方向に変化しない二次元的な部分が現れる。 それ 


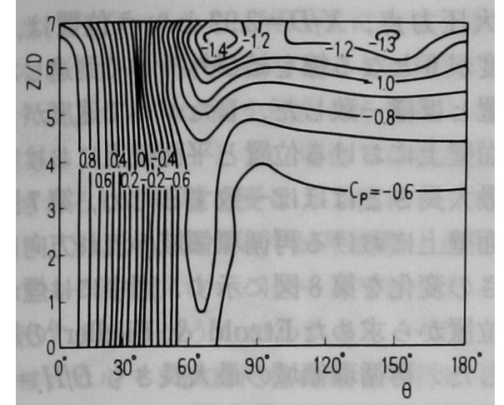

第 4 図 等王力線図 $(H / D=7)$

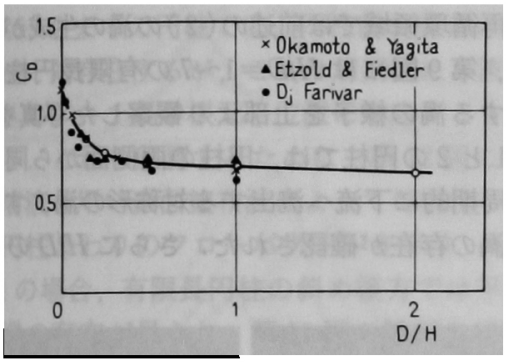

第 5 図 抗 力 保

と同時に円柱の自由先端より $0.5 D, \theta=70^{\circ}$ 付近の压 加谷に加えて, 背面の $\theta=140^{\circ}$ 付近に圧力の谷がさ らにもうーつ現れる. $H / D=7$ の円柱でカルマン渦 が生成され，この $\theta=140^{\circ}$ 付近のもう一つの圧力の谷 は， 円柱側面から制離したカルマン渦列の渦禾の一端 であることはすてに報告されている゙．したがって， $H / D=1$ の円柱のように $\theta=140^{\circ}$ 付近に王力の谷が現 れない場合は，丹柱側面から交互に流出するカルマン 洞仙存在しないことを意味している．この等圧力線図 加 $H / D=1$ の円柱から流出する渦と $H / D=7$ の円柱 から流出する瀜は異なったものてあることがわかる。

测定した側面の表面圧力分布より抗力係数を求め 3. 第 5 図に抗力保数 $\left(C_{\mathrm{D}}\right)$ を示す. 図中には Etzold \& Fiedler $\left(R e=3 \times 10^{4}\right)^{1)}$, Dj Farivar $(R e=7 \times$ $\left.10^{4}\right)^{2}$ ，岡本・八木田 $\left(R e=1.33 \times 10^{4}\right)^{3)}$ の結果を同時 に示した.この図より $D / H=0.25$ 付近（すなわち $H /$ $D=4)$ : り曲線が急潎に変化することが見られる。こ れは $H / D=7$ のように等圧力線図において圧力の谷が 二つ存在する場合，局所抗力係数は円柱先端付近て急 潡增加する．したがって，H/D=1のように圧力の 谷が一つしか存在しないものとは異なる．また $H / D$ $\leqq 4$ の円柱では $C_{\mathrm{D}}$ の值は比較的変化が少なく，小さ 以值てあるが，これは円柱自由先端部からの吹きおろ しが盗く，背面において圧力がかなり回復したことに よるものと思われる.また，二次元円柱ては吹きおろ しがなく，背面の静圧の回復がおそいため，平均抗力 (a) $H / D=1$

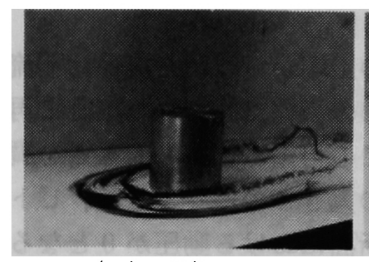

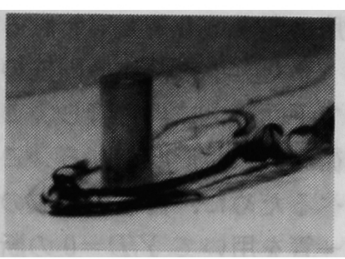

(b) $H / D=2$

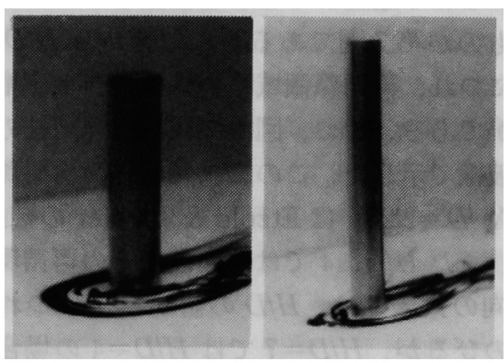

(c) $H / D=4 \quad$ (d) $H / D=7$

第6図馬 $\tau$ い渦

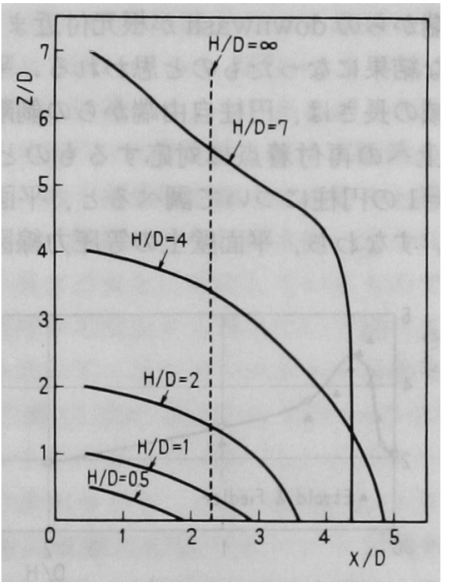

第 7 図 再循環領域の大きさ

係数は最大値を示すことからも毫付けられる。

3.2 渦の形成 円柱まわりの流れの場において は，次のような 2 種類の渦が存在する。

（1）円柱と平面壁との接続領域に発生する渦

（2） 円柱表面のはく離線の後方に発生する渦

平面壁上の円柱近くのはく離線の内側に馬てい形渦が 生し，この渦は円柱前方から両側をまわり，流れ方向 に軸をもち下流へ流れる．回流水暼を用い，インキ流 しの方法によって可視化観察を行うと第 6 図に示すよ うに馬てい形渦の存在が確認された．この馬てい形渦 の外側ては吹きあげ，内側には吹きおろしがあり，こ れが円柱後方の downwash を強める原因であると考 えられる．第6図を見ると $H / D$ の值が大きくなるに つれ，円柱高さに対する馬てい形渦の相対的大きさは 減少し，円柱自由先端からのdownwash を強める作 
用は弱まるものと思われる。

また，小縦横比の円柱の上端から離れた流線は下流 で平面壁上に再付着しここの流線で囲まれた内側に再 循票領域が形成される。この再盾環領域の大きさを調 べるために，再盾環領域の大きさの目安として，ピト 一管を用いて $Y / D=0$ の断面における動压が 0 となる 位置，すなわち速度が 0 となる位置を求め，その点を 結んだものが第 7 図である.この図から $H / D$ の値が 增えるにつれ，再循環領域の全体の大きさが増すこと が明らかである．なお，図中には二次元円柱の結果を 同時に破線で示した．この二次元円柱の再循環領域の 長さ $\left(X_{r} / D=2.25\right)$ は Etzold \& Fiedler の結果 ${ }^{1}$ と一 致した.また $H / D \leqq 4$ では地面板付近の再循環領域の 流れ方向の大きさは，H/Dの值が増すにつれ，下流 方向にのびるが, $H / D=7 て ゙ は H / D=4$ の場合に比べ て手前に，すなわち上流側にもどる。これは $H / D=7$ の場合、円柱自由端の影箱が先端部に限られることか ら，自由端からのdownwash が根元付近まで達せず， このような結果になったものと思われる. 平面壁上の 再循環領域の長さは，円柱自由端からの剥離した流れ の平面壁上への再付着点に対応するものと思われる が. $H / D=1$ の円柱について調べると，平面壁上への 再付着点，すなわち，平面壁上の等圧力線図の円柱下

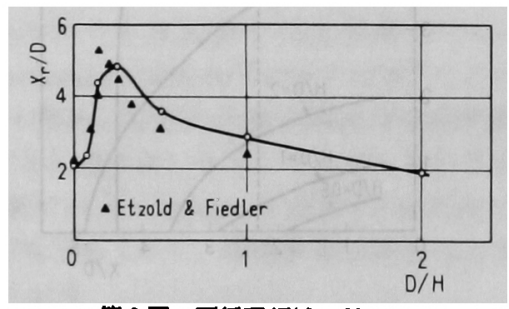

第 8 図 再循環領域の長さ

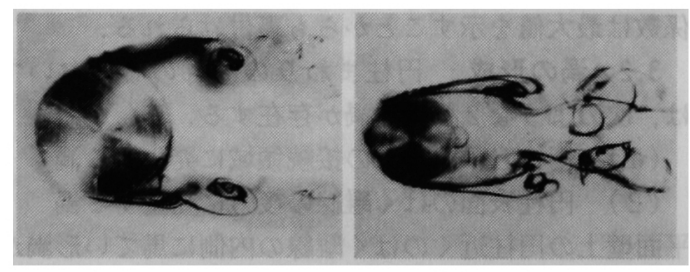

(a) $H / D=1$

(b) $H / D=2$

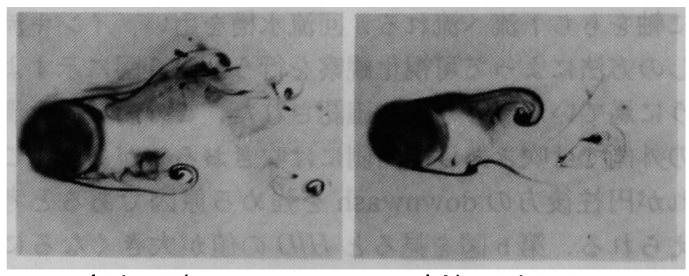

(c) $H / D=4$

(d) $H / D=7$

第9図 アーキ瀜，カルマン渦
流の最大圧力点， $X / D=2.92$ という位貪は，第 7 図 より速度が 0 となる線を結び外挿して到達した平面壁 上の位置とほほ一致した．したがって速度が 0 となる 線の平面壁上における位置と平面壁上における再循環 領域の最大長さとはほほ一致するため，第7図より求 めた平面壁上における再循環領域の流れ方向における 最大長さの変化を第 8 図に示す. 図中には煙が上流に もどる位置から求めた Etzold \& Fiedler")の結果を同 時に示した. 再循裐領域の最大長さも $D / H=0.25$ (す なわち $H / D=4 ）$ 付近に最大値をもち，それを境とし て変化の様子が異なることが明らかである。

この再循環領域ては前述の（2）の渦の生成が考えら れるが，第 9 図には $H / D=1 \sim 7$ の有限長円柱側面か ら流出する渦の様子を上部より観察した写真を示す. $H / D=1$ と 2 の円柱では，円柱の両側面から同時に制 離し，周期的に下流へ流出する対称形の渦，すなわち アーチ渦の存在が確認された．さらに $H / D$ の值を增

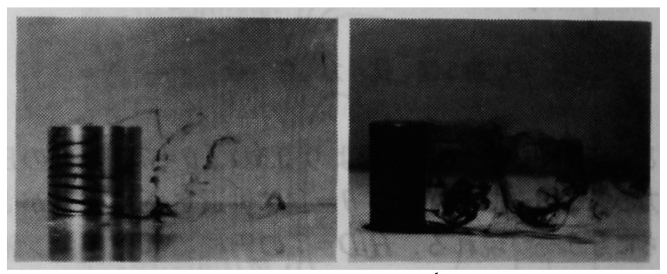

(a) $H / D=1$

(b) $H / D=2$

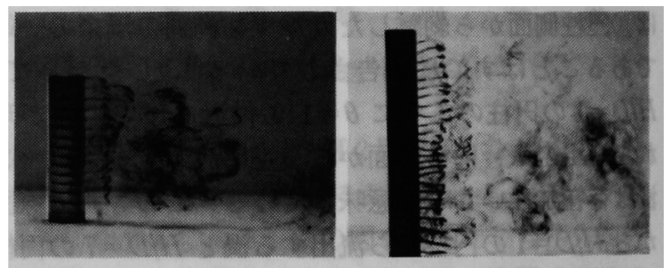

(c) $H / D=4$

(d) $H / D=7$

第 10 図 アーチ渦，カルマン渦

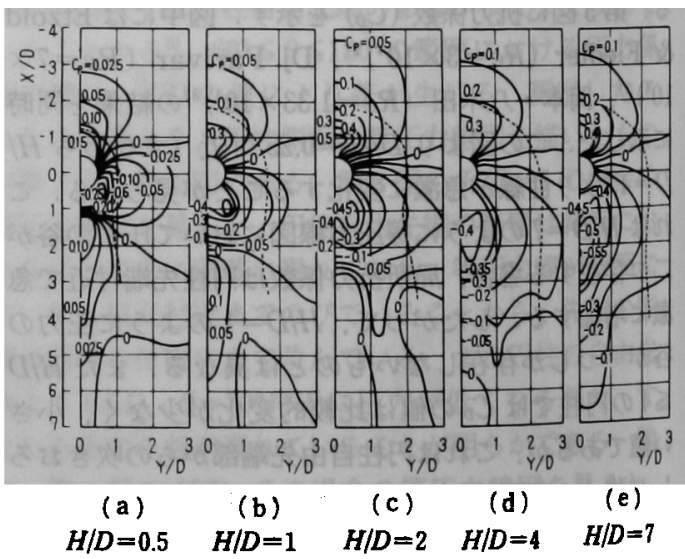

第 11 図 平面壁上の等圧力線図 
していき， $H / D=4$ から $H / D=7$ になると非対称形の 渦，すなわちカルマン渦になることが確認できた。

アーチ渦, カルマン渦を側面から観察したものが第 10 図である. $H / D=1$ と 2 の場合では流出したアーチ 渦加吹きおろしの影留を受け．下流にいくにつれて斜 めに㑯き, Savory \& $\operatorname{Toy}^{8)}$ が平面壁上の半球より流 出するアーチ渦のフローパターンで示したように，下 流に流出する様子がうかがわれる，一方， $H / D=7$ の 円柱ては，カルマン渦は円柱の軸と平行に下流に流出 する.これらの渦の動きは第 11 図に示されている平 面壁上の等圧力線図からも見られる。この図では $H /$ $D=0.5 \sim 2$ までの円柱では，円柱斜め後方に最小圧力 領域が一対存在するが、これは周期的に下流へ流れ出 たときのアーチ渦の根元の位置に対応するものと考え られる、これを確認するために、第 12 図に㐘みがき 粉の溶液を用い表面塗布法によって可視化した平面壁 上の円柱まわりのフローパターンを示す．（a）の H/ $D=1$ の場合, 有限長円柱の斜め後方では平面壁上に 双子渦の存在が見られ，第 11 図の等圧力線図から見 られる月柱後方の一対の最小圧力領域はこの双子渦の 位置に一致した。したがって先に述へた円柱背面の等 压力缐図で $\theta=140^{\circ}$ 付近に圧力の谷が現れない場合, 队柱からはアーチ渦が流出し，その渦禾の両端はこの 平面㮫上の最小圧力領域に位置し, 平面壁上の球, 半 球性体の場合")と同質の渦系てある。アーチ渦は、こ れらの根元の位置を軸として，先端からの強いdownwashによって斜めに傾き倒され，下流に流出する ものと考えられる。

さらに $H / D$ の值を増し， $H / D=4,7$ になと第 11 图に示されているように円柱後方の一対の最小圧力領 域はしだいにその間隔が接近し， $H / D=7$ の円柱では $Y / D=0$ 付近に一つの最小圧力領域を形成する .また 第 12 図(b)に示されている $H / D=7$ の有限長円柱ま わりのフローパターンでは $H / D=1$ の場合の双子渦の ような形とは異なり，渦が 1 カ所に集中したようにな
り，その位置は等圧力線図の一つの最小圧力領域の位 置とほほ一致した. 3.1 の表面圧力分布で $H / D=7$ の 円柱の場合，円柱背面の先端から $0.5 D, \theta=140^{\circ}$ 付近 の圧力の谷は側面からはく離したカルマン渦列の渦禾 の一端がその位置に固定されている場所であると述へ たが、この平面壁上の一つの最小圧力領域にはカルマ ン渦列の渦系の他端が位置している．このようにカル マン渦列の渦系は, その上端は円柱先端近くの背面， もう一方の下端が円柱直後の平面壁上にあることは， 岡本・八木田の $H / D=15$ の有限長円柱の水槽実験の結 果 ${ }^{3)} そ の$ 他の結果”においても明らかである。した がってカルマン渦の両端を結ぶ渦系は円柱に対して斜 めに傾いているようであるが9，これは円柱自由端か らの吹きおろしの影暗によるものである．また，カル マン渦の渦系の上端は, 先端より $0.5 D, \theta= \pm 140^{\circ}$ 付 近の左右の位置にあることから，自由端付近の渦の形 は，清水 ${ }^{9}$ が可視化しているように双子渦になってい る、第 11 図には平面壁上のはく離線を破線で示す. はく雕線は $H / D=1$ から $H / D=4$ までは $H / D$ の值を 増すと外側に位置するようであるが，それ以上増すと 岡本・八木田 ${ }^{3)}$ の水槽実験における結果のように内側 に位置し，はく離領域が縮小するものと思われる。な お，このはく離線の変化は第 8 図に示されている再循 環領域の長さの変化に対応しているものである．

次に円柱から流出する渦について調へるために熱線 流速計を用いてエネルギスペクトル分布を求める。一 例として第 13 図に $X / D=2, Y / D=0.5$ の位置におけ る $H / D=7$ の円柱での $Z / H$ によるエネルギスペクト ル分布の変化を示す $Z / H=0.04 \sim 0.43$ まではスペク トル行布に卓越周波数でのピークが現れているが,

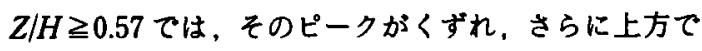
は存在しない。これはピークが存在する範囲では規則 的な流出渦が存在するものと考えられる．したがって

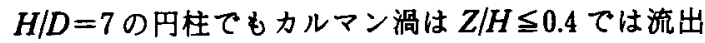
しているが、それより上方では周期的に流出するカル

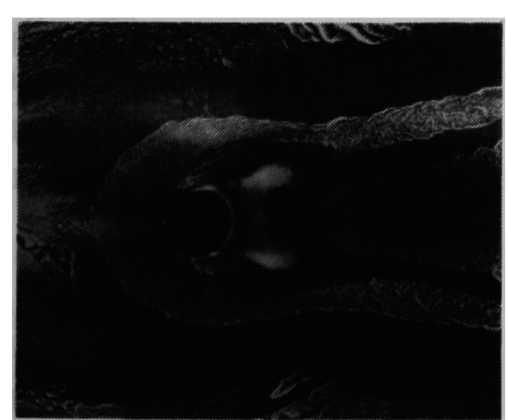

(a) $H / D=1$

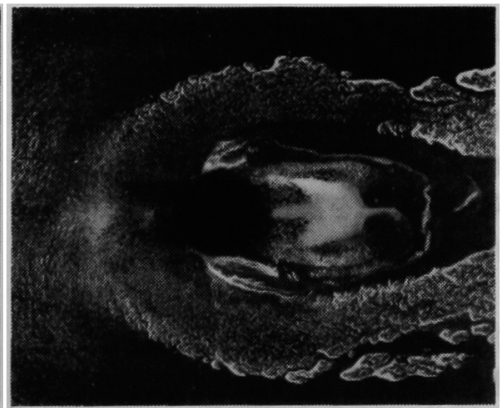

(b) $H / D=7$

第 12 図 平面鲜上の円柱まわりのフローパターン 

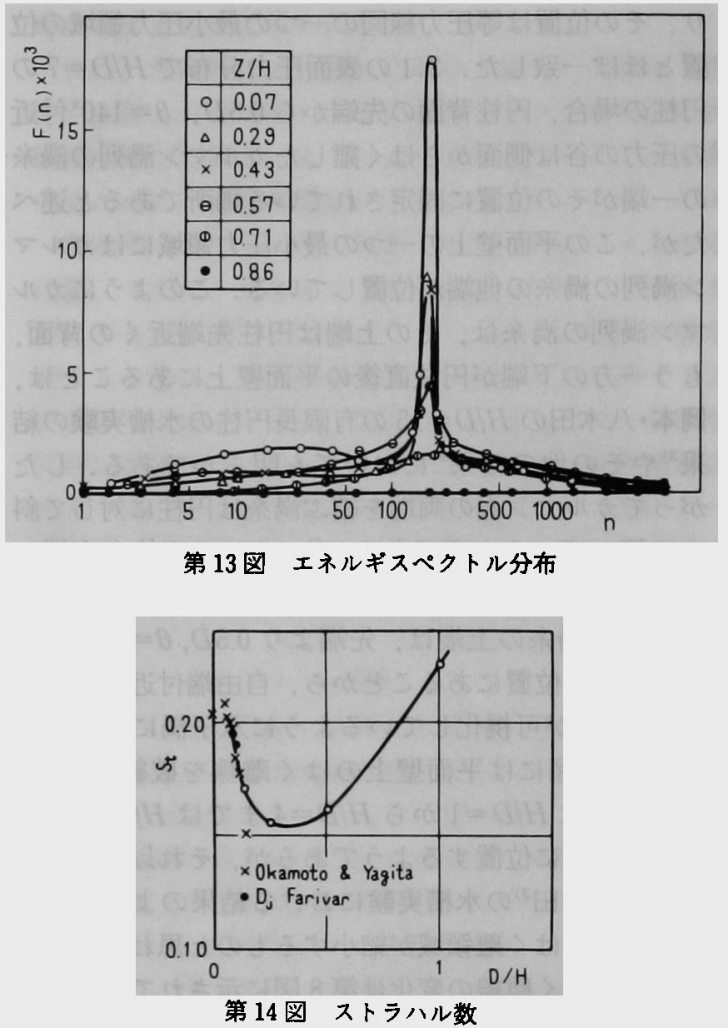

マン渦は自由先端からの吹きおろしの影響を受けて双 子渦のような形に変化するものと思われる. スペクト ル分布でピーク值をもつ卓越周波数より流出渦の $S t$ 数を求め，その結果を第 14 図に示す．この図を見る と $S t$ 数はアー千渦が流出している $H / D<4 て ゙ は ， H /$ $D$ の值が増すにつれ隇少し， $H / D=3$ 付近で最小値と なり，さらにカルマン渦が周期的に流出していると思 われる $H / D \geqq 4 て ゙ は ~ H / D$ の值を增すと再び増加する ことが明らかである。

3.3 乱流後流の速度，乱れ强さ分布 有限長円柱 の乱流後流は円柱先端からの吹きおろしが㮒の挙功に 影響を与えるので, 大気污染の問題に関連して重要性 をもっている。ここては円柱自由先端からの吹きおろ しを中心に調べることとする. 円柱下流の再循環領域 は $H / D=4$ の場合でも $X / D=4.85$ で終わり，その下 流には平面壁に浻ってせん断屇が形成される。この遠 隔後流の下流方向への変化を調べるために，第 15 , 16 図に $Z / H=0.5$ の水平面における速度欠損扔よび乱 れ強さの $X$ 方向， $Y$ 方向， $Z$ 方向成分の変化を示 す．なお，図中には二次元円柱の場合の結果を破線て 同時に示した．速度欠損分布をみると二次元円柱は $Y \mid D=0$ で最大值をもつ一つ山の分布形で下流に行く にしたがって最大速度欠損の值は減少し，後流が横に

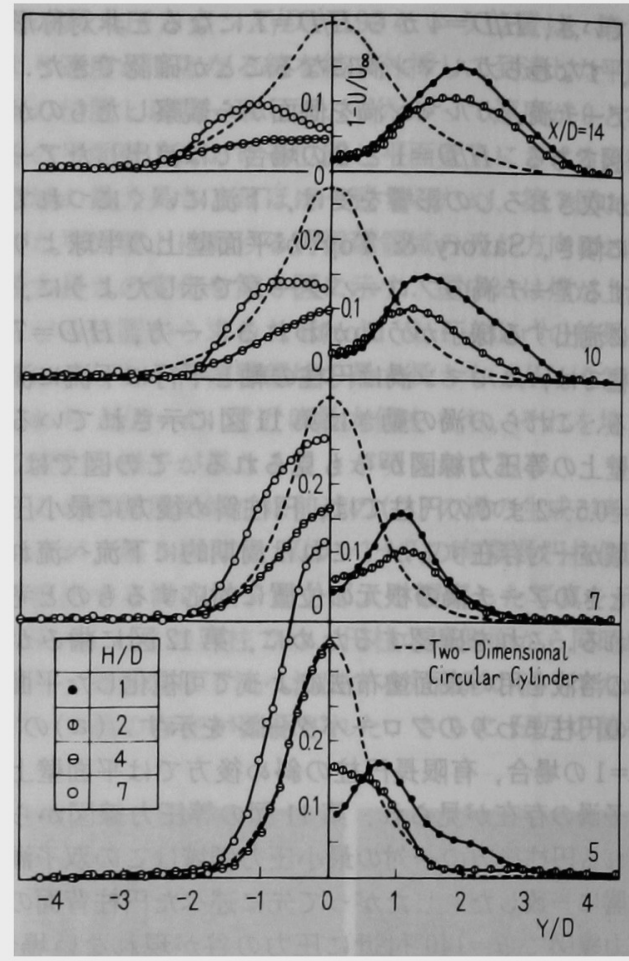

第 15 図 速度欠損分布 $(Z / H=0.5)$

ひろがっていくことが明らかである．H/D=1の円柱 の場合， $X / D=5 \sim 14$ において二つ山の分布形である が, $H / D=2$ の円柱の場合, $X / D=5$ ては一つ山， $X /$ $D \geqq 7$ では二つ山の分布形である. また $H / D=4$ の場 合は， $X / D=5 \sim 14 て ~ Y / D=0$ て最大值をもつ一つ山

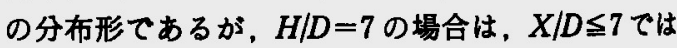
一つ山， $X / D \geqq 10$ では二つ山の分布形となる. ニつ 山の分布形は有限長円柱の後流の特色で, 円柱の自由 先端部からの主流が吹きおろすところでは速度欠損の $Y$ 方向分布に二つ山が現れる. 二つ山の中心部分は 主流の吹きおろしによる増速部分である。したがって $H / D=1$ の円柱では， $X / D=5$ でも円柱自由先端から の吹きおろしが及んでいることが明らかである。さら に $H / D$ の值を增すと， $H / D=2$ の円柱では， $X / D=5$ で柱先端からの吹きおろしの影䉕は現れず，円柱両 側面からの吹きこみによって一つ山の分布形である が，X/Dミ7では先端からの吹きおろしが現れ，二つ 山の分布形となる. また $H / D=4,7$ の円柱ては，H/D $=7$ の円柱が $X / D \geqq 10$ ては先端からの吹きおろしが 現れ、二つ山の分布形となるのに対し， $H / D=4$ の円 柱で， $X / D=14$ においてさえ，自由先端からの吹 きおろしが及ばず一つ山の分布形である．これは再看 環領域の長さが $H / D=4$ に比べて， $H / D=7$ の場合が 


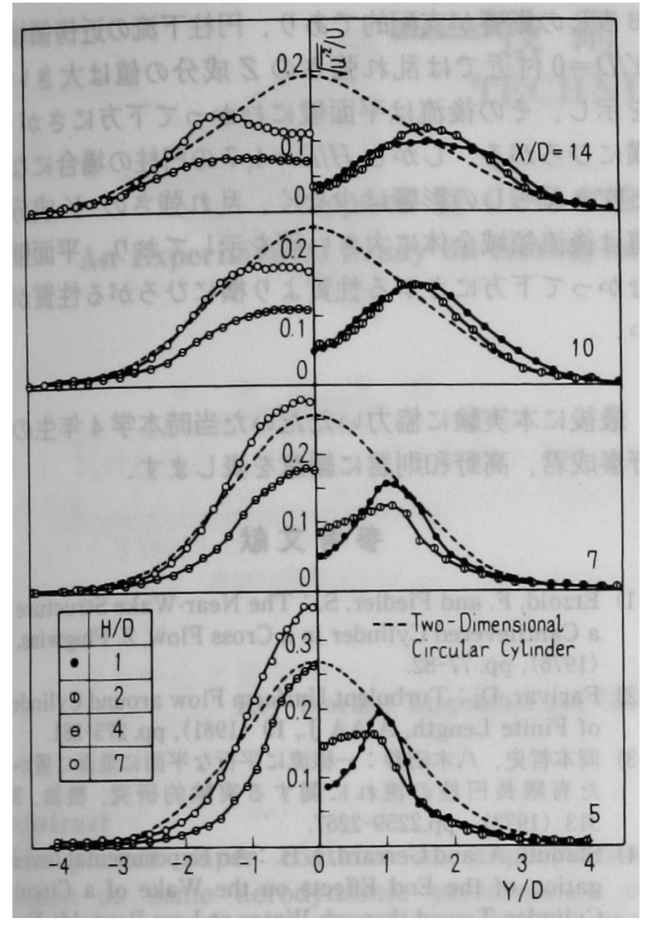

(a) $X$ 成分

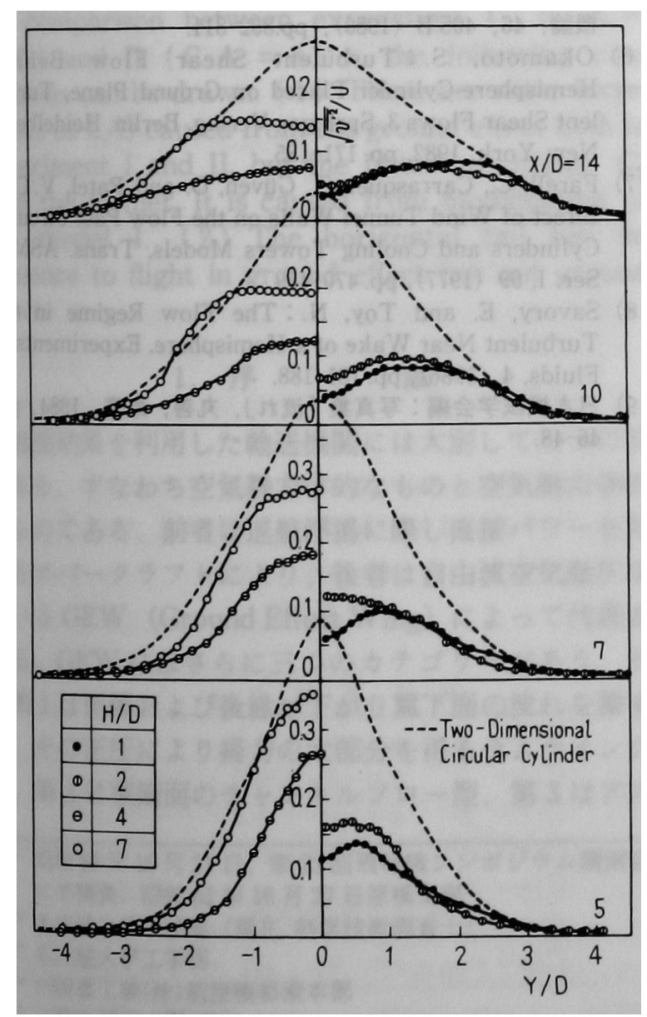

(b) $\boldsymbol{Y}$ 成分

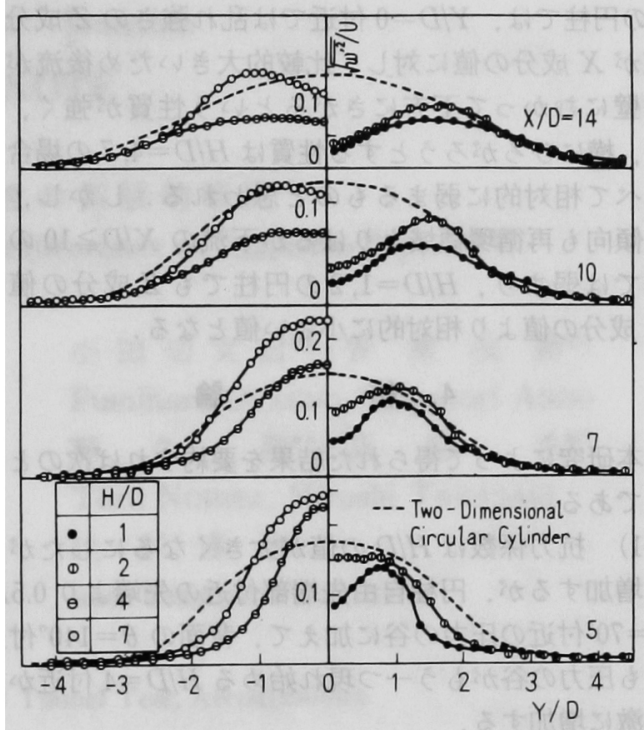

(c) $Z$ 成分

第 16 図乱れ強さ分布 $(Z / H=0.5)$

短く，したがってこの結果になったものと思われる. 全体的に分布形を見ると， $H / D=1,2$ と $H / D=4,7$ と いう二つの形に大別できる、これは第 8 図の再循環領 域の変化と密接な関係があると考えられ， $H / D=4$ を 境にして，H/D<4の場合では円柱自由先端からの吹

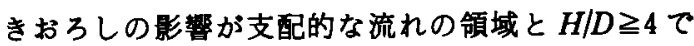
は，吹きおろしがほとんど及んていない流れが支配的 な領域というように二分される。

第 16 図に乱れ強さの各成分の下流に沿う変化を示 すが，全体的に分布形は速度欠損と同じうな変化を 示す. 乱れ強さの $X$ 成分と $Y$ 成分の大きさを比較す ると，先端からの吹きおろしの影望が現れる二つ山の 分布形となる $H / D=1,2$ の場合, $Y / D=0$ 付近ては乱 れ強さの $Y$ 成分は $X$ 成分より大きい。しかし，H/D $=4$ の場合では両成分の值はほほ等しく，さらに $H / D$ $=7$ ては, 後流全体にわたって $Y$ 成分は $X$ 成分より 大きい值である。これは $H / D=1,2$ の円柱では $Y / D$ $=0$ 付近で後流が横にひろがろうとする性質は比較的 強いが，それ以外の領域では弱く，H/D=7の円柱に なると二次元円柱の場合と同じく，後流領域全体にわ たって横方向にひろがるという性頁が強くなるものと 思われる。また円柱後方の $X / D=5,7$ という近傍領 域では, $H / D=1,2$ の円柱の場合, $Y / D=0$ 付近の乱 れ強さの $X$ 成分と $Z$ 成分の大きさがほほ近い值であ るのに対し， $H / D=4,7$ の円柱ては $Z$ 成分の值は $X$ 成分の值よりかなり小さい，したがって，乱れ強さの $Y, Z$ 成分の大きさの変化を考えあわせると $H / D=1$, 
2 の円柱では， $Y / D=0$ 付近では乱れ強さの $Z$ 成分の 值が $X$ 成分の值に対し，比較的大きいため後流が平 面壁にむかって下方にさがるという性質が強く，ま た，横にひろがろうとする性質は $H / D=4,7$ の場合と 比べて相対的に弱まるものと思われる.しかし，そ の傾向も再循環領域よりはるか下流の $X / D \geqq 10$ の範 囲では弱まり， $H / D=1,2$ の円柱でも $Z$ 成分の值は $X$ 成分の值より相対的に小さい值となる。

\section{4. 結論}

本研究によって得られた結果を要約すれば次のとお りである。

1）抗力保数は $H / D$ の值が大きくなるにしたがつ て増加するが, 円柱自由先端部付近の先端より $0.5 D$, $\theta=70^{\circ}$ 付近の圧力の谷に加えて, 背面の $\theta=140^{\circ}$ 付近 にも圧力の谷がもう一つ現れ始める $H / D=4$ 付近から 急激に增加する。

2) 円柱まわりの馬てい渦の円柱高さに対する相対 的大きさは，H/Dの值が大きくなるにつれ滅少し， したがって円柱自由先端からの吹きおろしを強める作 用は $H / D$ の值が大きくなるにつれ弱まる。

3） 円柱後方の再循環領域の全体の大きさは $H / D$ の值が增加するにしたがって増す。しかし平面壁付近 の下流方向の最大長さは $H / D$ の值が増加するにした 増え， $H / D=4$ 付近で最大值に達するが，さらに $H / D$ の值を増すと隇少する。

4) 円柱側面から流出する渦は，H/D=1,2ではア 一チ渦, $H / D=4$ から $H / D=7$ にかけてカルマン禍へ と移行する.この流出渦の $S t$ 数は、アーチ渦が流出 している領域では $H / D$ の值が増すと減少し， $H / D=3$ $\sim 4$ 付近では最小值となり,さらに $H / D$ の值を増し, カルマン渦が流出している領域では再び增加する.

5） 円柱後方の後流は速度欠損分布，乱几強さ分布 から見て， $H / D=1,2$ の場合，自由先端部からの吹き
おろしの影響が支配的であり．円柱下流の近傍領域の $Y / D=0$ 付近では乱れ強さの $Z$ 成分の值は大きい值 を示し，その後流は平面壁にむかって下方にさがり， 横にUろがる。しかし $H / D=4,7$ の円柱の場合になる と吹きおろしの影響は少なく，乱れ強さの $Y$ 成分の 值は後流領域全体に大きい值を示しており。平面壁に むかって下方にさがる性質より横にひろがる性質が強 い.

最後に本実験に協力いただいた当時本学 4 年生の菅 野泰成君，高野和則君に謝意を表します。

\section{参考文献}

1) Etzold, F. and Fiedler, S. : The Near-Wake Structure of a Cantilevered Cylinder in a Cross Flow, Z. Flugwiss, 24 (1976), pp. 77-82.

2) Farivar, $\mathrm{Dj}:$ Turbulent Uniform Flow around $C y$ linders of Finite Length, AIAA J., 19 (1981), pp. 275-281.

3）岡本哲史，八木田幹：一様流に平行な平面に垂直に置加n た有限長円柱の流れに関方る実臨的研究，機論，38. 313 (1972), pp.2259-2267.

4) Slaouti, A. and Gerrard, J. H. : An Experimental Investigation of the End Effects on the Wake of a Circular Cylinder Towed through Water at Low Reynolds Num. bers, J. Fluid Mech., 112 (1981), pp. 297-314.

5）谷口清一，坂本弘志，有江幹男：乱流境界居の中に存在す る直立円柱周辺の流れ（円柱の直径と高さが異なる場合） 機論，46，405 B (1980)，pp.802-811.

6) Okamoto, S.: Turbulent Shear Flow Behind Hemisphere-Cylinder Placed on Ground Plane, Turbulent Shear Flows 3, Springer-Verlag, Berlin, Heidelberg, New York, 1982, pp. 171-185.

7) Farell, C., Carrasquel, S., Guven, O. and Patel, V.C. : Effect of Wind Tunnel Walls on the Flow Past Circular Cylinders and Cooling Towers Models, Trans. ASME, Ser. I, 99 (1977), pp. 470-479.

8) Savory, E. and Toy, N.: The Flow Regime in the Turbulent Near Wake of a Hemisphere, Experiments in Fluids, 4 (1986), pp. 181-188.

9）日本機械学会編：写真集「流れ」，丸普，東京，1984，pp， 46-48. 